\section{International Scientific Journal Theoretical \& Applied Science}

p-ISSN: 2308-4944 (print) e-ISSN: 2409-0085 (online)

Year: $2016 \quad$ Issue: 9 Volume: 41

Published: $30.09 .2016 \quad$ http://T-Science.org
Kamola Davlyataliyevna Saipova

PhD in History, Docent

National University of Uzbekistan,

Tashkent, Uzbekistan

kamola_nuz@rambler.ru

SECTION 13. Geography. History. Oceanology. Meteorology.

\title{
FORMATION UZBEK SSR AND INFLUENCE UPON LIFE NATIONAL MINORITY (1924-1925 y.)
}

Abstract: Question about creation national statehood fair asiatic folk is considered this question as very complex and required the all-round study, serious preparation to undertaking national-state fission in CENTRAL ASIA.

Key words: national fission, formation UZSSR, nation, national minority, Central Asia.

Language: English

Citation: Saipova KD (2016) FORMATION UZBEK SSR AND INFLUENCE UPON LIFE NATIONAL MINORITY (1924-1925 y.). ISJ Theoretical \& Applied Science, 09 (41): 111-113.

Soi: http://s-o-i.org/1.1/TAS-09-41-16 Doi: crossef http://dx.doi.org/10.15863/TAS.2016.09.41.16

\section{Introduction}

National fission in CENTRAL ASIA and formation UZSSR - a result social and economic development of the country. In turn, this second revolution, which has fundamentally changed the national relation a nation, lived on territory of the Central Asia. The First revolution were on call the russian proletariat (the October 1917.). This was a first revolution, most solving revolution, without which impossible liberation nation and nationalities. The Second revolution is identified state-national fission. This was in root wrong if we valued fission Central Asia only, as narrow-practical reform of local internal importance, determination of the necessary borders on national fission, nationalcultural construction and etc.

\section{Materials and Methods}

What wrote I.Vareykis "We consider that fission between nations and national problem to Central Asia on area the most complex and tangled in national attitude, we before all world, before all folk of the Orient, particularly prostrating from national oppression, spare once prove that our policy rests on the most great conquest of the October, get fat liberty, independence and equality toilling nation to former tsarist empire".[1, p.41] Important stage on way of the formation Uzbek SSR was a creation Turkestan ASSR, as well as Bukhara and Horezm Public Soviet Republics. Fission on national sign in that concrete condition was inadvisable, since it distracted nation, lived in Central Asia, from decision main questioning - a question about the authorities.

Starting-up work on fission in Central Asia were begin; start; commence party long before 1924 As far back as 1920 was lifted question about creation national government each of folk of the Central Asia and was put(deliver)ed problem "to form the card (ethnographic and other.) Turkestan with subdivision on Uzbek, Kyrgyzstan and Turkmenistan; detailed to realize the condition of the merging or division these 3 parts". [2, p.58-59] In 1924 Politburo CK RKP (b), CK RKP (b), central committees to communist parties Turkestan, Bukhara and Horezma repeatedly discussed on meeting question about national-state fission in Central Asia. During discussion of this question on places were brought forth different offers, from which some were shown obviously wrong. So, group Fergana workman at January 1924 has emerged with offer about separation Fergana area on rights by person of the autonomous unit. On joint meeting Sredazbyuro CK RKP (b) and executive agency CK KPT January 131924 were considered question, lifted Fergana's people. Sredazbyuro CK RKP (b) and executive agency CK KPT in its resolution have noted "fallaciousness of the offer ферганских workman. Fission in Central Asia must was be conducted, first of all, on national sign". [3, p.59] March 23-24 1924 meeting of the plenum CK KPT took place in Tashkent together secretary regional, large district and town committee to parties. The question was 
discussed On plenum about national-territorial fission Turkestan. The Plenum has noted that stating the question about such fission well-timed. The offers were voiced about separation from composition Turkestan ASSR several autonomous national republics; about undertaking fission only Turkestan ASSR, not touching Bukhara and Horezm; about creation federations.

In Bukhara row of the party members offered that Uzbek republic has united Bukhara and uzbek parts Turkestan and Horezm. The Capital Uzbekistan appeared to do or Bukhara, or Samarkand. There were disputes and about that, what republic must belong to Tashkent and etc.

On meeting Sredazbyuro CK RKP (b) of the April 281924 at addressing the issues about fission was voiced opinion about that to form in CENTRAL ASIA several autonomous republics and unite them in federation. However, 11 May 1924 Sredazbyuro CK RKP (b) has taken resolution, in which was spoken:

"1. Acknowledge necessary to produce fission on national-territorial sign now existing Central Asian of the republics (BNSR, TASSR and HNSR), not forming federations from newly chosen nationalterritorial associations.

2. Organize: but) Uzbek and Turkmen republic on rights independent SSR with direct entering in USSR; b) Punishment-Kirghiz autonomous area, having left opened question about that, in composition what republics she enters; g) include the kirghiz, inhabitting Turk republic", in now existing Kirghiz republic. [4, p.61] Coming from accepted resolutions possible to draw a conclusion that Sredazbyuro CK KRP (b) greatly drew near its glance to interest, which were recognized "correct" CK RKP (b).

On the grounds of resolutions about nationalstate fission republics to Central Asia were created organizing commissions on count; calculate; list state formation for convocation convention Advice of the national soviet republics and autonomous areas.

Simultaneously 4-I Exceeding session CIK Advice Turkestan ASSR November 181924 has resolved: "1. Activity CIK Advice, SNK and Economic Advice to stop, having sent whole fullness authorities on corresponding to territory of the republic revolutionary committee newly formed republics and autonomous areas. 2. The Liquidation property and questions, having importance, form the liquidation committee, operating on the basis of person about him positions". Soon, the Revolutionary committee Uzbek SSR was formed. Several later at February 1925 Presidium VCIK has confirmed the resolution SNK RSFSR about abolition Turk komissii.

On the strength of that that former Bukhara and Horezm republics became socialist shortly before national fission, in these republic laws and other state acts differed from laws and acts RSFSR. Considering this circumstance, its resolution from November 27 1924 Revkom Uzbek SSR has founded the special commission on revising of the laws former Bukhara and Horezm republics and entering the united laws on the whole territory Uzbekistan.

In its appeal Revkom UZSSR was noted that "national policy soviet authorities is expressed in full equality all nation. So Revolutionary committee UZSSR declares that hereafter on territory UZSSR no place national antagonism. All national minority, falling into UZSSR, is provided all necessities for cultural and economic development, in the sense of management, court and enlightenments on native language". [5, p.3] Many aspects given appeals disagreed real reality that confirms the following facts. the December 51924 are daytime formation Uzbek SSR. "February 131925 work I Constituent convention advice Uzbekistan began in Bukhara. In functioning(working) the convention has took part 517 delegates with solving and 81 delegates with consultative voice. A representatives were On convention from all folk, inhabiting territory UZSSR, including from Tadzhik ASSR, be included in UZSSR- 64 delegates with solving voice and 2 delegates with consultative voice".

As a whole, $12 \%$ has formed the delegate with solving voice and $2 \%$ with delegate by consultative voice. These factors speak of that that representatives not all folk were attracted in the course of work I Constituent convention.

\section{Conclusion}

On territory of the Central Asia that is to say on territory TASSR Bukhara and Horezm, was expected build three republics and two autonomous areas: Uzbek, Turkmen and Kirghiz republic and autonomous areas: Karakalpakskiya and Tadzhik. The Territory of the Uzbek Republic formed beside 400 thous. square miles with population in 5.000.500-5.000.600 thous. The National composition was exceedingly motley: the most multiple group of the population were shown Uzbeks. They formed $60 \%$ and were concentrated in the following terrain: in Fergana valley, in valley yard Chirchik, in valley of the rivers Zarafshan, Saizar, a part Kashkadarya, on lower current yard Pyandzha and on upper current Amudarii and on some her(its) influx, but in the same way upper current Amudarya and on some her(its) influx. The Suppressing majority uzbek lived in city Fergana, Tashkent, Chimkent, Turkestan, Dzhizak, Kattakurgan, Hive and Bukhara.[6, p.20] Following on the number of the groups presented the kirghizs and kazakhs (19\%). On advantage were shown nomad, but in 20-e years $\mathrm{HH}$ age strong pulling to husbandry has destroyed amongst them purely nomadic facilities, which in general formed very small percent. They lived basically in steppe 
Syrdariya and Dzheytun area, in song Kyzylkum, on Ustyurt, on lower reached Amudarya, in valley of the rivers Angren and Keles, in region Nurata.

The Punishment-kirghizs or buruts (wildly stone kirghizs) (9\%) lived on declivity west pullSHanya, in Alaysk valley, in foothill Alaysk mountains, East Pamir and in south part Dzheytun area (Pishpek and Przhevalisk districts). The Small groups their met as in Syrdaria area, so and in Samarkand. Rather compact mass of the vein on west declivity Gissarsk mountains and on declivity ridge Petra Great in Bukhara (Karategin).[7, p.21] Turkmens $(8 \%)$ lived the utter mass in Turkmen area on valley of the rivers Atreka, Sumbara, Tedzhena and Murgaba, on north foothill Kopetdag, on average current Amudariya (Kerkinsk and Charzhusk district BSSR) and on south extremity Hivinsk oasis.

Karakalpaks $(1 \%)$ ed only in do Amudariya though met very small in number their groups in valley yard Chirchika and in Fergane. Kurama (1\%) - a mixture uzbek, kazak and tadzhik natoins, lived in valley yard Angren and are diffused were amongst the other nationalities in Samarkandskoy area, in Buhare and even in Turkmen area.[8, p.21] Kipchaki
$(0,9 \%)$ ed only in Fergan area. The Small groups met in nearby district Dzhetysu area. Taranchi $(0,9$ $\%$ ) presented the result of the melange Turks with iranian, themselves they ranked itself to Turks. In Turkistan they were resettled from Iliyskogo edges (the West China), lived in valley yard Or, Almaatin and Dzharkents district Dzhetysu area. The Iranian a tadzhiks $(8 \%)$ lived in Samarkand area, in Bukhara and in west part Pamir. In Samarkand area lived in south and south-east mountain part and in city Samarkand, Pendzhikent, Uratyube, Hodzhent. In Bukhara they lived in Karategin, Kulyab and Balidzhu region, on upper current Amudariya. Besides, in the same way beside $8 \%$ all tadzhik lived in Fergana (and small groups lived in mountain parts Syrdariya area.

The rest mass of the population constituted of russian $(10 \%)$, Armenians, jew, hindu, arab, dungan (whole 0,2 \%) and etc. The Economic Uzbek Republic was considered the most powerful from all Central Asian republics. Here the most developping was marketability of the agriculture, the main market were disposed within republic.[10, p.47]

\section{References:}

1. Vareykis I, Zelenskiy I (1924) National-state fission Average Azii. - Tashkent: Sredneaziatskoe state publishers, 1924. - pp.41.

2. Agzamhodzhaev A, Urazaev SH (1960) Development soviet in Uzbekistane. - Moscow: State publishers legal literature, 1960. - pp.5859.

3. Agzamhodzhaev A, Urazaev SH (1960) Development soviet in Uzbekistane. - Moscow: State publishers legal literature, 1960. - pp.59.

4. (1924) The Truth of the Orient. December 5 1924. - pp. 10.

5. Agzamhodzhaev A, Urazaev SH (1960) Development soviet in Uzbekistane. - Moscow: State publishers legal literature, 1960. - pp.66.
6. Nemchenko M (1925) National fission Average Azii. - M.: Publishing NKVD. 1925. - pp.20

7. Nemchenko M (1925) National fission Average Azii. - M.: Publishing NKVD. 1925. - pp.21.

8. (1946) The Essay of the culture kirghiz naroda. - Frunze: Izd-in Kirghiz of the branch AN USSR, 1946. - pp.7.

9. Nemchenko M (1925) National fission Average Azii. - Moscow: Publishing NKVD. 1925. pp.21.

10. Vareykis I., Zelenskiy I. National-state fission Average Azii. - Tashkent: Sredneaziatskoe state publishers, 1924. - pp.46-47 